\title{
Sistem Informasi Prioritas Pengembangan Infrastruktur Menggunakan Metode Hanlon Berdasarkan Investasi Warga Desa Sekapuk
}

\author{
Infrastructure Development Priority Information System Using Hanlon \\ Method Based on Investment of Sekapuk Villagers
}

\author{
Taka Fidihama ${ }^{{ }^{*}}$, Achmad Teguh Wibowo ${ }^{2}$, Nita Yalina ${ }^{3}$ \\ 1,2,3)Program Studi Sistem Informasi, Fakultas Sains dan Teknologi \\ Universitas Islam Negeri Sunan Ampel \\ Jl. A.Yani No. 117, Wonocolo, Surabaya, Indonesia. \\ *email: h06215012@uinsby.ac.id
}

DOI;

10.30595/jrst.v4i1.4992

Histori Artikel:

Diajukan:

$29 / 07 / 2019$

Direvisi:

$05 / 02 / 2020$

Diterima:

$10 / 03 / 2020$

\section{ABSTRAK}

Dalam penelitian ini membahas tentang metode hanlon untuk menyelesaikan permasalahan pada perencanaan pembangunan infrastruktur Wisata Bukit Kapur Setigi. Dalam melakukan pembangunan infrastruktur Bukit Kapur Setigi, Kepala Desa Sekapuk merancang program Tabungan Plus Investasi (Taplus Invest). Sumber dana pembangunan infrastruktur diperoleh dari masyarakat dengan melakukan investasi untuk berpartisipasi membangun Bukit Kapur Setigi menjadi destinasi wisata. Permasalahan pada pembangunan Bukit Kapur Setigi yaitu terbatasnya dana dalam melakukan pembangunan, sehingga diperlukan prioritas agar pembangunan dapat optimal. Salah satu alternatif pemecahan masalah tersebut adalah dengan membangun sebuah sistem yang mampu menghasilkan rekomendasi untuk prioritas pembangunan infrastruktur, beserta pencatatan dan pelaporan secara real-time. Sehingga dapat meminimalisir kesalahan dalam proses pencatatan transaksi. Dengan adanya sistem informasi pencatatan dan prioritas pembangunan infrastruktur berbasis web dapat membantu pimpinan dalam mengambil keputusan untuk memprioritaskan pembangunan infrastruktur. Karena Bukit Kapur Setigi merupakan potensi destinasi wisata yang mampu untuk menarik wisatawan mancanegara. Hasil yang di dapatkan adalah rekomendasi prioritas pembangunan infrastruktur dari sistem dibuktikan dari hasil penghitungan pada metode Hanlon.

Kata Kunci: Hanlon, investasi, penentuan prioritas.

\begin{abstract}
This research discusses the Hanlon method to solve problems in planning the development of Bukit Kapur Setigi Tourism infrastructure. The Sekapuk Village Chief designed the Savings Plus Investment program (Taplus Invest). Infrastructure development funds are obtained from the community by investing in building Setigi Kapur Hill to become a tourist destination. The problem with the construction of the Kapur Setigi Hill is the limited funds in carrying out development. One alternative to solve this problem is to build a system that is able to produce recommendations for priority infrastructure development using the Hanlon method, along with recording and reporting in real-time. With the existence of a recording information system and the priority of web-based infrastructure development can help leaders in making decisions to prioritize infrastructure development. Because Bukit Kapur Setigi is a potential tourist destination that is able to attract foreign tourists. So that it can increase the income of Sekapuk Village residents through tourism.
\end{abstract}

Keywords: Hanlon, Investment, Priority reference. 


\section{PENDAHULUAN}

Desa Sekapuk merupakan sebuah desa yang terletak di Kecamatan Ujung Pangkah, Kabupaten Gresik, Provinsi Jawa Timur. Desa Sekapuk memiliki kekayaan alam berupa gunung kapur. Sebagai desa yang memiliki kekayaan alam berupa gunung kapur, sebagian besar warga desa sekapuk bermata pencaharian menggali gunung kapur untuk dijadikan bata putih. Aktivitas penggalian terus dilakukan hingga pada tahun 2017 Kepala Desa beserta masyarakat setempat timbul kesadaran akan potensi wisata Bukit Kapur Setigi. Pembangunan berupa infrastruktur diperlukan pada kawasan Bukit Kapur Setigi dalam mewujudkan Bukit Kapur Setigi sebagai destinasi wisata. Oleh karena itu, Kepala Desa setempat membangun program Tabungan Plus Investasi (Taplus Invest) dalam proses penggalian dana untuk pembangunan infrastruktur pada kawasan wisata Bukit Kapur Setigi.

Taplus Invest merupakan nama program yang diselenggarakan oleh Kepala Desa Sekapuk, yang dimaksudkan bagi setiap warga Desa Sekapuk untuk dapat berinvestasi pada pembangunan Wisata Bukit Kapur Setigi. Dengan cara menabung sebesar Rp. 8.000,- per hari. Setelah jumlah tabungan terkumpul senilai Rp. 2.400.000,- nasabah memiliki hak untuk dapat memiliki satu slot saham, dengan jumlah maksimal 2 slot untuk setiap NIK pada wisata Bukit Kapur Setigi atau dana yang telah terkumpul dikembalikan secara utuh. Sehingga dalam proses jangka panjang, masyarakat Desa Sekapuk yang menjadi pemegang saham mendapatkan keuntungan dari pemasukan wisata Bukit Kapur Setigi.

Metode Hanlon merupakan alat yang digunakan untuk membandingkan berbagai masalah yang berbeda-beda dengan cara relative dan bukan absolute, framework, seadil mungkin dan objektif. Cara yang digunakan untuk menentukan prioritas masalah dengan menggunakan 4 kelompok kriteria, yakni: Besarnya masalah (magnitude), tingkat keseriusan masalah (emergency), Kemudahan penanggulangan masalah (causability), Faktor yang menentukan dapat tidaknya program dilaksanakan (PEARL factor). Sehingga dalam rangka evaluasi dan bahan pertimbangan dalam menyusun strategi dan pengembangan mutu pelayanan yang lebih baik lagi(R, Fudholi, \& W, 2013). Sehingga dapat diperoleh hasil yang dapat digunakan sebagai bahan pertimbangan pengambilan keputusan dalam menentukan prioritas pembangunan infrastruktur wisata Bukit Kapur Setigi.
Bimmaharyanto dan Fudholi (2017) membuktikan bahwa metode Hanlon mampu memberikan rekomendasi strategi perbaikan, sehingga dengan melakukan analisis dengan metode Hanlon mampu memberikan strategi perbaikan kepada Instalasi Farmasi RSUD Kabupaten Bima guna meningkatkan nilai skor kesesuaian terhadap standar akreditasi pelayanan farmasi.

Wirdah dan Achmad (2013) meneliti bahwa metode Hanlon memberikan analisis prioritas rencana perbaikan tindakan pada Instalasi Farmasi Rumah Sakit Umum Daerah Karel Sadsuitubun Kabupaten Maluku Tenggara, sehingga tahapan pengelolaan obat yang belum sesuai dengan standar akreditasi dapat dikurangi.

Ristiawati dan Latif (2015) meneliti bahwa metode Hanlon mampu menentukan prioritas permasalahan kesehatan di desa simbang wetan kabupaten pekalongan, sehingga penyusunan program kesehatan dalam mengendalikan permasalahan kesehatan dengan tepat dapat terlaksana berdasarkan prioritas dari permasalahan.

Diterapkannya sistem informasi penentuan prioritas pembangunan infrastruktur dengan menggunakan metode Hanlon, maka proses pelaporan pencatatan investasi dapat berlangsung secara real time tanpa harus menunggu pelaporan secara manual. Sesuai dengan peraturan pemerintah tentang BUMD yang akuntabel. Pada tahap selanjutnya sistem akan menghitung prioritas pembangunan infrastruktur mana yang perlu didahulukan, sehingga pihak Kepala Desa dapat didukung dalam proses pengambilan keputusan pembangunan infrastruktur. Sehingga cita-cita Desa Sekapuk dalam membangun Desa Wisata Bukit Kapur Setigi yang berdampak terhadap kesejahteraan warga sekitar dapat tercapai.

Paper ini disusun sebagai berikut: bagian 2 menunjukkan bagaimana metode penelitian yang digunakan, bagian 3 membahas hasil dan pembahasan dalam penelitian ini, sedangkan kesimpulan ditunjukkan pada bagian 4 . 


\section{METODE PENELITIAN}

Metode penelitian yang digunakan dalam pembuatan Sistem Informasi Penentuan Prioritas Infrastruktur digambarkan pada Gambar 1.

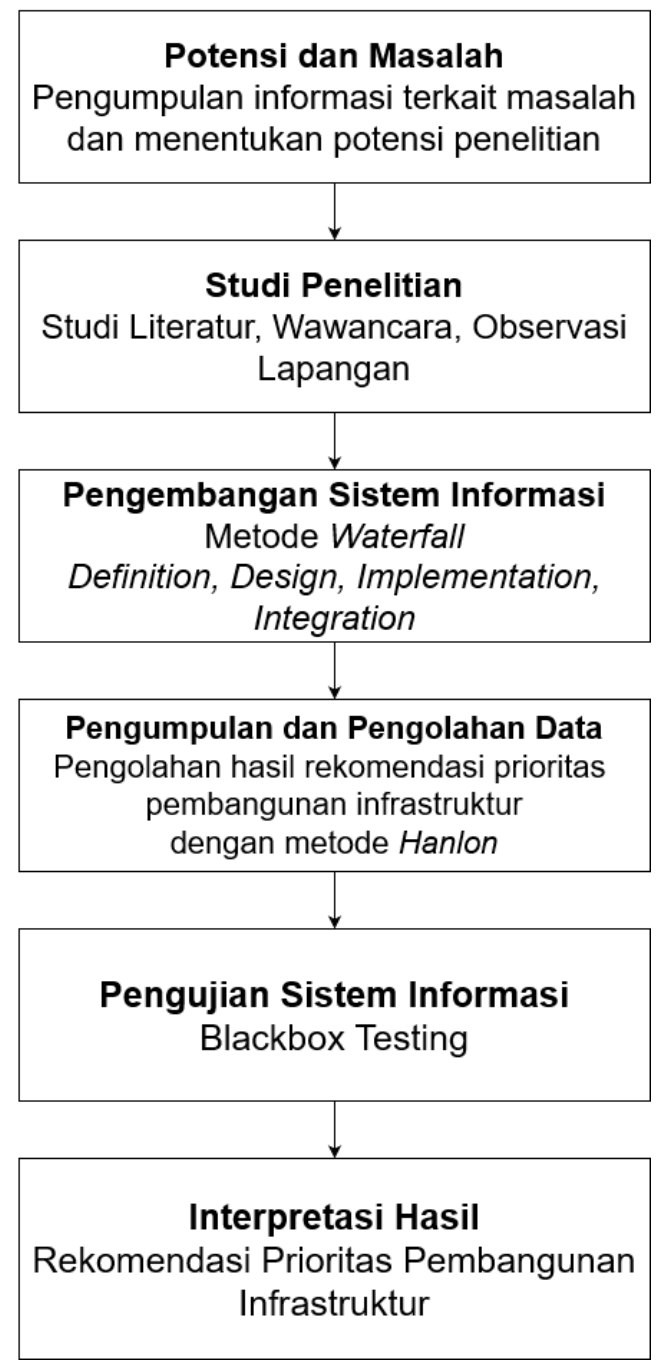

Gambar 1. Metode Penelitian

a) Potensi dan Masalah

Desa Sekapuk yang teletak pada Kabupaten Gresik Kecamatan Ujungpangkah merupakan sebuah desa dengan kekayaan alam berupa gunung kapur. Diawali dengan kedatangan pengunjung mancanegara yang secara tidak sengaja, perlahan masyarakat mulai menyadari akan potensi wisata dari Bukit Kapur Setigi. Dalam satu tahun terakhir pimpinan desa mengembangkan program bernama Taplus Invest, dengan tujuan membangun infrastruktur pada wisata Bukit Kapur Setigi, sehingga mengubah Desa Sekapuk yang tidak hanya menjadi desa penghasil kapur, namun juga menjadi sebuah Desa Wisata. Sejalan dengan rencana pembangunan infrastruktur, proses pencatatan pendapatan dari investasi yang dilakukan oleh warga masih dilakukan secara manual, belum ada sistem informasi mengenai pencatatan dari pendapatan investasi tersebut. Sistem Informasi penentuan prioritas sangat dibutuhkan karena mampu memberikan pelaporan secara real-time tentang aliran dana investasi warga dan melalui Sistem Pendukung Keputusan yang disematkan dengan metode Hanlon, pimpinan yang terkait dapat terbantu dalam memilih prioritas pembangunan infrastruktur.

b) Studi Penelitian

Pada tahap studi penelitian dilakukan pengumpulan data pendukung penelitian guna mendukung keberlangsungan penelitian. Data dukung yang dimaksud yaitu data yang relevan dengan penelitian, seperti identifikasi sistem saat ini di lapangan, identifikasi alur proses bisnis pada desa dan lain sebagainya, teknik pengumpulan data menggunakan studi literatur, observasi dan wawancara.

c) Perancangan

Pada tahap perancangan merupakan tahap merancang segala yang dibutuhkan dalam penelitian seperti, kerangka dari produk penelitian. Produk penelitian yang dimaksud adalah Sistem Informasi, kerangka dari produk penelitian dapat berupa Use Case Diagram dan Activity Diagram, basis data mengenai sistem yang akan dikembangkan.

d) Pengolahan Data

Pada tahap pengolahan data yaitu mengumpulkan dan melakukan pengolahan data berupa bobot dari masing-masing kriteria yang telah diisikan oleh responden melalui web sistem yang telah dibuat. Dalam penelitian ini menggunakan metode Hanlon, metode ini menentukan hasil rekomendasi berdasarkan 4 kelompok kriteria: magnitude(A), emergency (B), causability $(C)$, PEARL factor $(D)$ (R et al., 2013). Berikut ini adalah rumus dari metode Hanlon

$$
\begin{aligned}
& \text { Nilai Prioritas Dasar } \\
& =(A+B) * C \\
& \begin{aligned}
\text { Nilai Prioritas Total } \\
=(A+B) * C * D
\end{aligned}
\end{aligned}
$$

Dimana:

A merupakan nilai dari besarnya masalah dari setiap masalah dengan rentang 0-10. B merupakan jumlah dari tingkat keseriusan setiap masalah dengan memiliki faktor sebanyak $\mathrm{n}$ dan jumlah nilai keseluruhan maksimal 20. Persamaan dari B ditunjukkan:

$$
\sum_{i \leq 20}^{n} X i=X 1+X 2+\ldots+X n
$$


C merupakan nilai dari kemudahan penanggulangan setiap masalah dengan rentang nilai 1-10. D merupakan nilai dari setiap faktor PEARL dengan nilai 0 atau 1.

e) Pengembangan

Pada tahap pengembangan yaitu mengembangkan prototype sistem informasi sesuai dengan hasil perancangan produk. Metode dalam mengembangkan aplikasi ini mengadopsi dari metode pengembangan Waterfall.

f) Pengujian

Pada tahap pengujian yaitu menguji prototipe sistem informasi menggunakan metode black box, pengujian menggunakan metode black box testing akan menguji prototipe sistem dari segi alur kerja sistem, pengujian dilakukan oleh pakar yang dianggap mampu melakukan pengujian terhadap prototipe sistem informasi menggunakan metode black box.

g) Interpretasi Hasil

Pada tahap interpretasi hasil yaitu tahap menyajikan hasil pengolahan data. Data yang telah diperolah akan dihitung ke dalam perhitungan metode Hanlon, sehingga dapat diketahui hasil akhir berupa urutan dari prioritas permasalahan.

\section{HASIL DAN PEMBAHASAN}

\subsection{Analisis Prosedur Tabungan Plus Investasi}

Dari program daerah yang diterapkan oleh Kepala Desa Sekapuk, kegiatan program Tabungan Plus Investasi merupakan sebuah kegiatan yang dirancang untuk warga Desa Sekapuk dalam berpartisipasi untuk berinvestasi sebesar Rp. 8000,- per hari atau sampai terkumpul dengan Rp. 2.400.000,- per 1 slot saham guna meningkatkan potensi dari Bukit Kapur Setigi. Gambar 2 menunjukan hasil analisis prosedur tersebut.

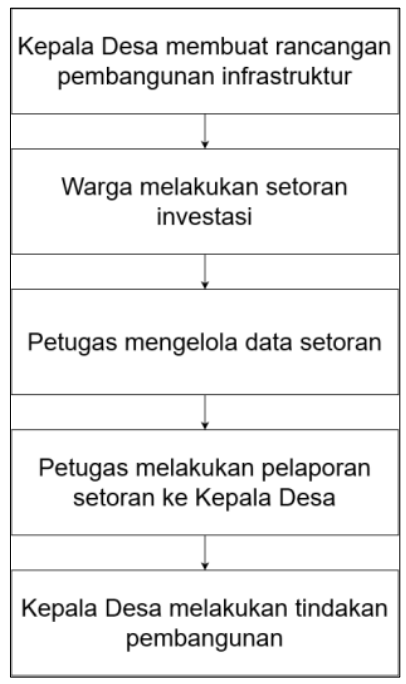

Gambar 2. Prosedur Tabungan Plus Investasi yang berlaku

\subsection{Perancangan Alur Sistem}

Dalam melakukan perancangan sistem informasi penentuan prioritas, menggunakan Unified Modelling Language (UML). Diagram UML dirancang menggunakan software Microsoft Visio. Berikut diagram UML yang digunakan dalam perancangan sistem informasi penentuan prioritas.

\subsection{Use Case Diagram}

Use Case Diagram menggambarkan hak akses dari setiap aktor / role dalam sistem, perancangan dari sistem informasi penentuan prioritas terbagi dalam 3 hak akses yaitu warga, admin dan kepala desa, Gambar 3 menunjukan use case diagram yang digunakan.

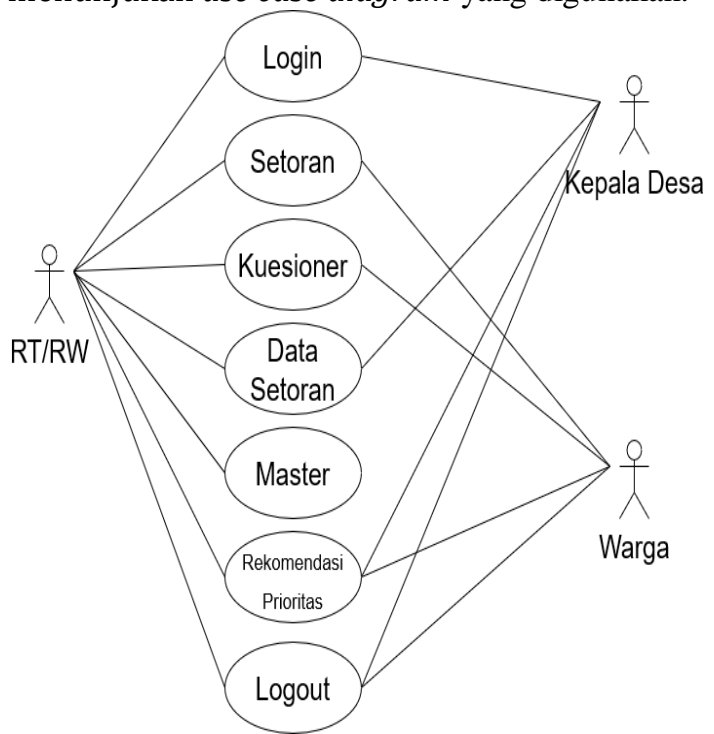

Gambar 3. Use Case Diagram

\subsection{Activity Diagram}

Activity Diagram Setoran merujuk pada hak akses warga dan hak akses admin. Hak 


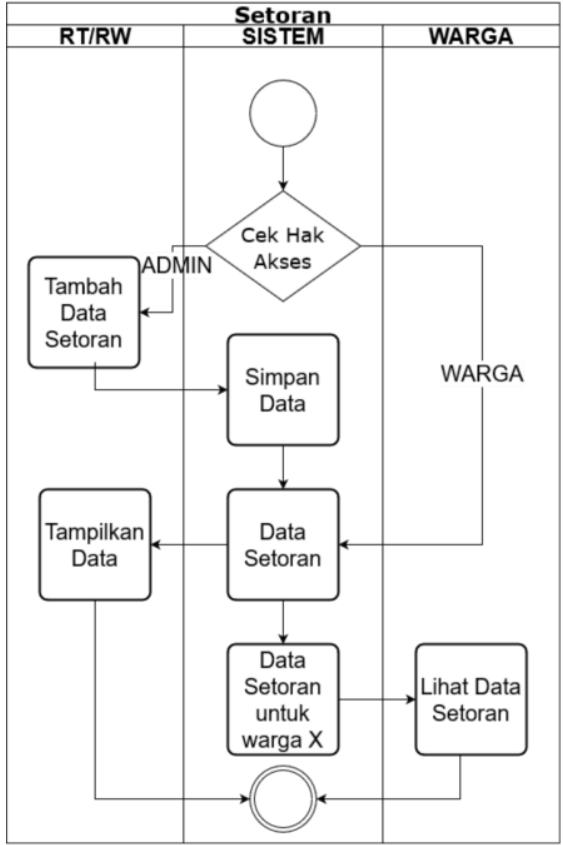

(a)

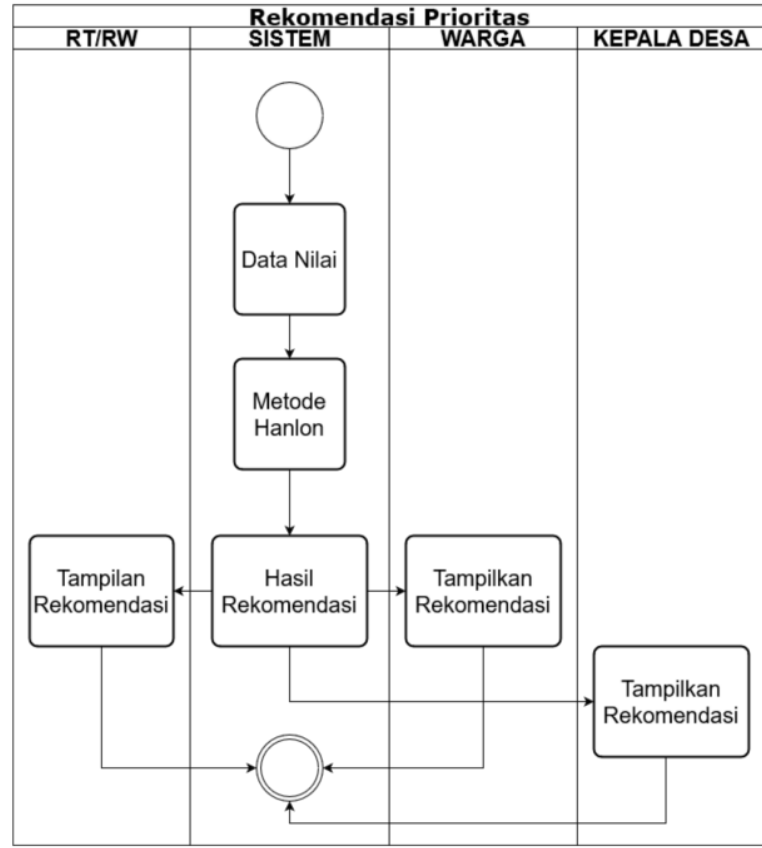

(b)

Gambar 4. Activity diagram (a)setoran, (b)rekomendasi prioritas

akses warga dapat melihat riwayat dan hasil rekap setoran miliknya. Sedangkan pada hak akses admin memiliki wewenang tambahan yakni melakukan penambahan data. Gambar 4(a) menunjukan activity diagram setoran yang digunakan.

Activity Diagram Rekomendasi Prioritas merujuk pada seluruh hak akses pada sistem informasi. Dimana setiap aktor / role dapat melihat rekomendasi prioritas pembangunan berdasarkan perhitungan metode Hanlon oleh

\subsection{Perancangan Database}

Penggunaan basis data merupakan sebagai tujuan media penyimpanan data dari sistem informasi yang berjalan. Perancangan struktur basis data dilakukan dengan tahap modelling atau biasa disebut dengan diagram Conceptual Data Model (CDM). Berikut adalah gambaran dari struktur basis data yang dirancang untuk sistem informasi penentuan prioritas menggunakan metode Hanlon. Gambar 5 menunjukkan desain database

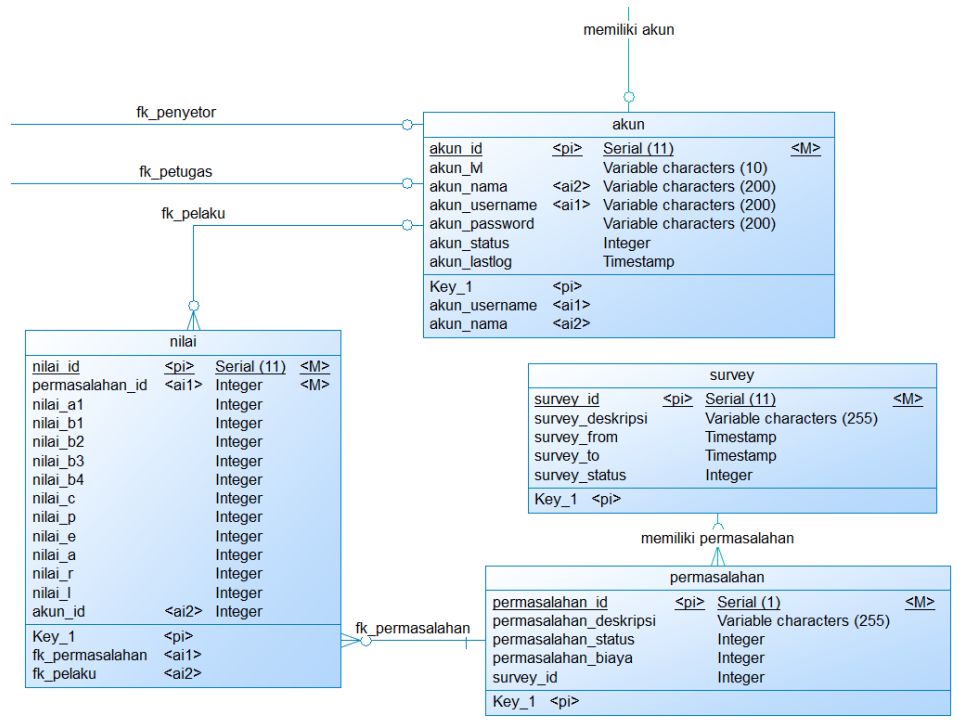

Gambar 5. Desain Database metode Hanlon

sistem. Gambar 5 menunjukkan activity diagram rekomendasi prioritas yang digunakan metode Hanlon dan Gambar 6 menunjukkan desain database sistem informasi. 


\subsection{Implementasi}

Berdasarkan perancangan antarmuka yang dibuat, dilakukan implementasi dari perancangan tersebut menjadi sebuah tampilan antarmuka pada sistem berbasis website agar memudahkan pengguna dalam menggunakan sistem yang telah dibangun. Metode Hanlon digunakan dalam menentukan rekomendasi prioritas pembangunan infrastruktur menggunakan persamaan (1) untuk menentukan Nilai Prioritas Dasar dengan parameter: (A) besaran masalah yang mempunyai rentang nilai 1-10, (B) tingkat keseriusan masalah menggunakan persamaan
(3), (C) kemudahan dalam penanggulangan masalah dengan rentang nilai 0-10, dimana semakin besar nilai menunjukkan kemudahan masalah dapat ditanggulangi.

Untuk menghitung Nilai Prioritas Total menggunakan persamaan (2) dengan parameter seperti penentun Nilai Prioritas Dasar dikali dengan parameter (D) PEARL factor yang didapat dari input pengguna. Gambar 7 menunjukkan User Interface Sistem Informasi.

\subsection{Pengujian Sistem Informasi}

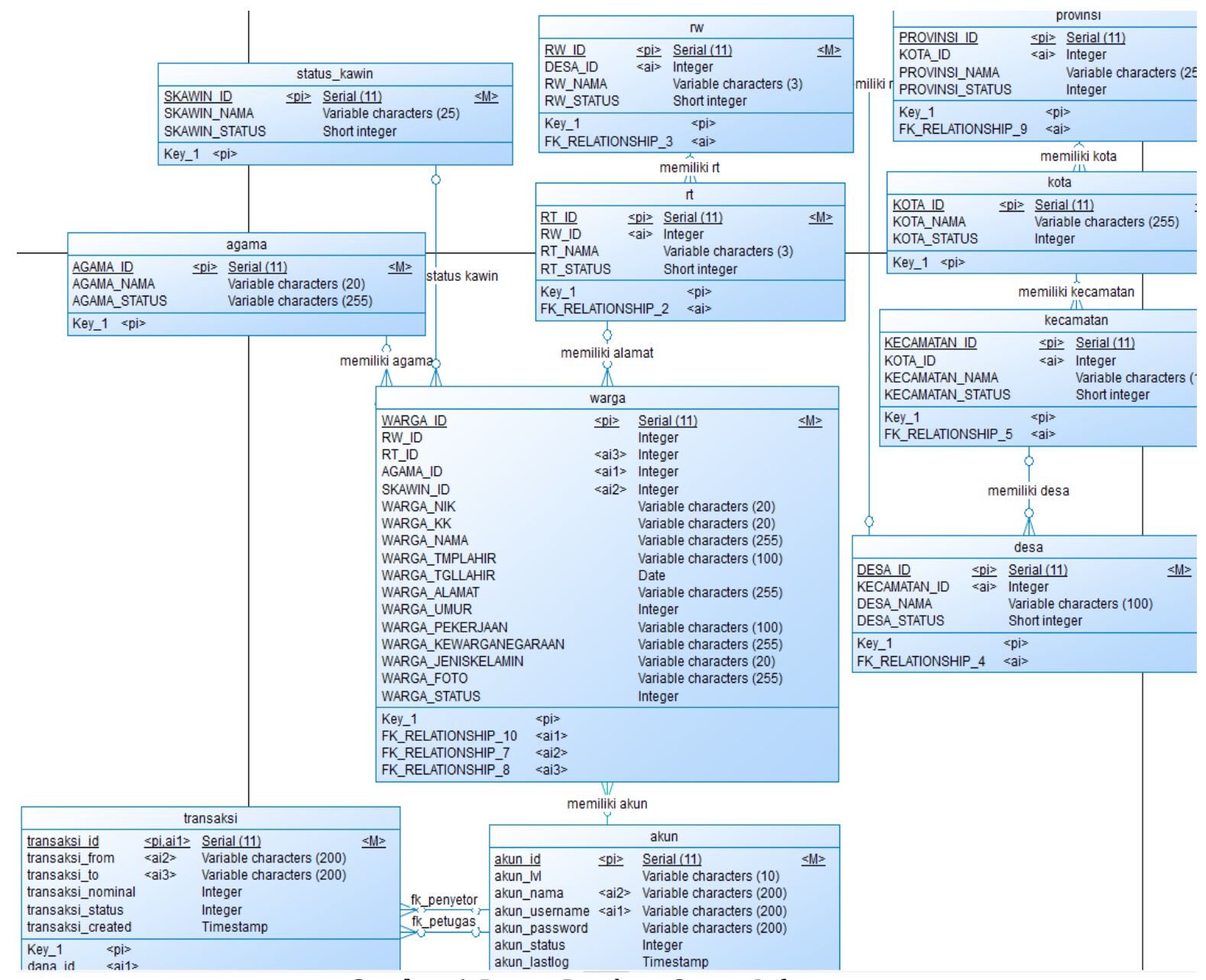

Gambar 6. Desain Database Sistem Informasi 

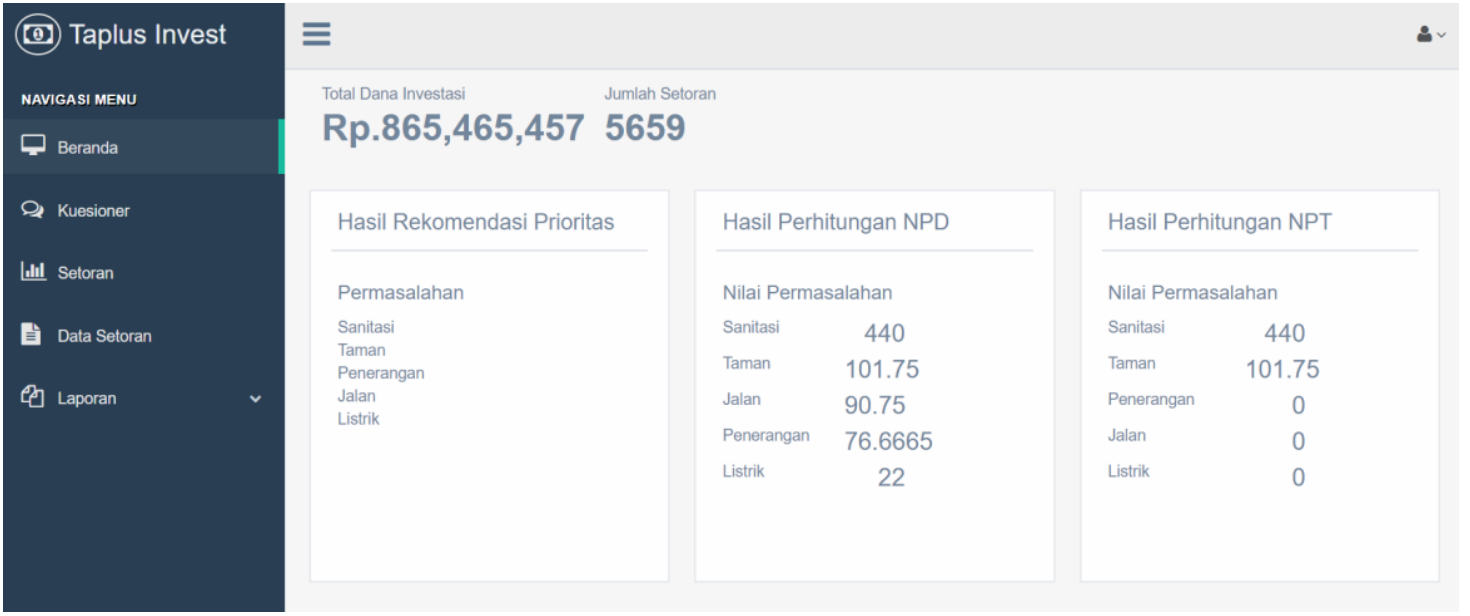

Gambar 7. User Inteface Sistem Informasi

Pengujian sistem informasi dilakukan melalui tahap pengujian, yakni dilakukan Blackbox Testing untuk melakukan pengujian terhadap kesesuaian alur kerja sistem.

Dalam pengujian black box dilakukan oleh Muhammad Vrodin, Founder CV. Vromedia Informatika Teknologi. Pertimbangan pemilihan penguji karena memiliki kompetensi dalam melakukan pengujian sistem informasi menggunakan metode black box testing. Hasil pengujian ditunjukan pada Tabel 1.

Tabel 1. Instrumen pengujian black box testing

\begin{tabular}{|l|l|l|l|}
\hline No & Aktivitas & $\begin{array}{l}\text { Hasil yang } \\
\text { diharapkan }\end{array}$ & $\begin{array}{l}\text { Berhasil } \\
\text { /Tidak }\end{array}$ \\
\hline 1 & Login & $\begin{array}{l}\text { Masuk } \\
\text { kedalam } \\
\text { sistem dengan } \\
\text { validasi } \\
\text { Username dan } \\
\text { Password }\end{array}$ & Berhasil \\
\hline 2 & Setoran & $\begin{array}{l}\text { Melihat dan } \\
\text { membuat data } \\
\text { setoran }\end{array}$ & Berhasil \\
\hline 3 & Kuesioner & $\begin{array}{l}\text { Mengisi data } \\
\text { pembobotan } \\
\text { metode } \\
\text { Hanlon }\end{array}$ & Berhasil \\
\hline 4 & Data Setoran & $\begin{array}{l}\text { Melihat data } \\
\text { setoran secara } \\
\text { global Babahasil }\end{array}$ & Berhasil \\
\hline 5 & Master & $\begin{array}{l}\text { Menambah, } \\
\text { melihat, } \\
\text { mengubah, } \\
\text { menghapus } \\
\text { data pada } \\
\text { modul master, } \\
\text { seperti warga, } \\
\text { permasalahan, }\end{array}$ & \\
\hline
\end{tabular}

\begin{tabular}{|l|l|l|l|}
\hline No & Aktivitas & $\begin{array}{l}\text { Hasil yang } \\
\text { diharapkan }\end{array}$ & $\begin{array}{l}\text { Berhasil } \\
\text { /Tidak }\end{array}$ \\
\hline 6 & $\begin{array}{l}\text { Rekomendasi } \\
\text { user. dan }\end{array}$ & $\begin{array}{l}\text { Melihat hasil } \\
\text { rekomendasi } \\
\text { prioritas } \\
\text { pembangunan } \\
\text { infrastruktur }\end{array}$ & Berhasil \\
\hline 7 & Logout & $\begin{array}{l}\text { Keluar dari } \\
\text { sistem }\end{array}$ & Berhasil \\
\hline
\end{tabular}

Melalui pengujian diperoleh hasil dari 7 fungsi aktivitas inti yang diujikan. Berdasarkan hasil tersebut diperoleh persentase keberhasilan sistem sebesar $100 \%$ secara fungsionalitas menggunakan black box testing.

\section{KESIMPULAN}

Sistem Informasi Penentuan Prioritas Pembangunan Infrastruktur adalah sistem informasi berbasis web, menggunakan bahasa pemrograman PHP dengan MySQL sebagai DBMS. Sistem mampu membantu Kepala Desa Sekapuk dengan memberikan rekomendasi prioritas pembangunan infrastruktur sesuai dengan masukan yang telah dilakukan kedalam sistem, melalui metode Hanlon dengan melakukan perhitungan pada Komponen A, Komponen B, Komponen C dan Komponen $\mathrm{D}$ dari nilai-nilai yang telah diisikan warga pada masing-masing komponen. Evaluasi sistem dilakukan dengan black box testing, pengujian dilakukan oleh pakar. Dari hasil pengujian secara fungsionalitas berdasarkan pakar, 7 aktivitas yang telah diujikan dinyatakan berhasil. Sehingga sistem memperoleh persentase keberhasilan sistem $100 \%$. 


\section{DAFTAR PUSTAKA}

Bimmaharyanto, D. E. S., Fudholi, A., \& W, G. P. (2017). EVALUASI TINGKAT KESESUAIAN STANDAR AKREDITASI TERHADAP PELAYANAN FARMASI DAN STRATEGI PERBAIKAN DENGAN METODE HANLON DI RSUD KABUPATEN BIMA. 3(2), 209215.

Daqiqil, I. (2011). Framework Codeigniter Sebuah Panduan dan Best Practice. Pekanbaru, (May), 1-120.

DINHUBKOMINFO Jateng \& Komisi Informasi Jawa Tengah. (2013). Peraturan Perundang-Undangan Keterbukaan Informasi Publik.

Eddy, H. (2007). Manajemen Operasi. In Manajemen Operasi.

Hamidi, J. (2016). Paradigma Baru Pembentukan Dan Analisis Peraturan Daerah (Studi Atas Perda Pelayanan Publik Dan Perda Keterbukaan Informasi Publik). Jurnal Hukum Ius Quia Iustum, 18(3), 336-362. https://doi.org/10.20885/iustum.vol18.i ss3.art3

Kamaliah, K. (2015). Implementasi UndangUndang Nomor 14 Tahun 2008 Tentang Keterbukaan Informasi Publik Di Badan Perencanaan Pembangunan Daerah Kota Samarinda. E-Journal Ilmu Pemerintahan, Vol 3 No 2(2), 1113-1125. Retrieved from ejournal.ip.fisipunmul.ac.id/site/wp-content/.../jurnal (08-31-15-09-41-07).pdf\%0A\%0A

Krisma, I., Lidya, F., Oktaviani, R., Ayu, A., \& Dkk. (2015). Tahap Penentuan Prioritas Masalah Metode Hanlon \& Tahap Analisis Akar Penyebab Masalah Fish Bone. 1-28.

Nimas. (2016). Pengertian Dan Contoh Data
Flow Diagram (DFD) atau Diagram Alir Data (DAD). Retrieved May 5, 2019, from https://www.pro.co.id/pengertian-dancontoh-data-flow-diagram-dfd/

Prabowo, R. D. (2014). Implementasi UndangUndang Keterbukaan Informasi Publik dalam Upaya Mewujudkan Good Governance( Kajian Tiga Badan Publik: Bappeda, DPKAD dan Dinas Pendidikan Kota Semarang ). 1-33.

R, W. W., Fudholi, A., \& W, G. P. (2013). Evaluation of Drugs Management and Improvement Strategies Using Hanlon Method in the Pharmaceutical Installation of Hospital in 2012. Evaluation of Drugs Management and Improvement Strategies Using Hanlon Method in the Pharmaceutical Installation of Hospital in 2012, 283-290.

Radhitya, Y., Nur Hakim, F., \& Solechan, A. (2016). Rancang Bangun Sistem Pendukung Keputusan Penentuan Penerima Beasiswa Dengan Metode SAW. Jurnal Speed - Sentra Penelitian Engineering Dan Edukasi, 8(2), 23-32.

Ristiawati, \& Latif, R. V. N. (2015). IDENTIFIKASI PERMASALAHAN KESEHATAN DI DESA SIMBANG WETAN KECAMATAN BUARAN KABUPATEN PEKALONGAN TAHUN 2015. 5(1), 71-77.

Scavarda, A., Bouzdin-Chameeva, T., \& Goldstein, S. (2004). A review of the causal mapping practice and research literature. Second World Conference ..., 612-624. Retrieved from http://scholar.google.com/scholar?hl=en \&btnG $=$ Search\&q=intitle:A+Review + of $+\mathrm{t}$ he+Causal+Mapping+Practice+and+Rese arch+Literature\#0 